\title{
Association of Maternal, Obstetric and Neonatal Variables on the Use of Bronchial Hygiene Maneuvers and Impact on Morbidity, Mortality and Survival in Neonatal Intensive Care Unit
}

\section{Lucio Flavio Garcia Rodrigues ( $\nabla$ lucioflavio99@gmail.com )}

Federal University of Pará (UFPA)

Emerson Souza Da Rocha

Federal University of Pará (UFPA)

Isabelle Coelho da Silva

University of Amazon - ESAMAZ, Brazil

Luciana de Fátima da Costa Moraes

University of Amazon - ESAMAZ, Brazil

Laura Maria Tomazi Neves

Federal University of Pará (UFPA)

Denise da Silva Pinto

Federal University of Pará (UFPA)

Natália Silva da Costa

UNIVERSITY OF AMAZON - UNAMA

João Simão de Melo-Neto

Federal University of Pará (UFPA)

\section{Research Article}

Keywords: Intensive Care Units, Pregnancy, Infant mortality, Respiratory system, Survival analysis

Posted Date: April 15th, 2021

DOl: https://doi.org/10.21203/rs.3.rs-378915/v1

License: (c) (i) This work is licensed under a Creative Commons Attribution 4.0 International License.

Read Full License 


\section{ORIGINAL ARTICLE}

ASSOCIATION OF MATERNAL, OBSTETRIC AND NEONATAL VARIABLES ON THE USE OF BRONCHIAL HYGIENE MANEUVERS AND IMPACT ON MORBIDITY, MORTALITY AND SURVIVAL IN NEONATAL INTENSIVE CARE UNIT

\section{ASSOCIAÇÃO DE VARIÁVEIS MATERNAS, OBSTÉTRICAS E NEONATAIS NO USO DE MANOBRAS DE HIGIENE BRÔNQUICA E IMPACTO NA MORBIDADE, MORTALIDADE E SOBREVIVÊNCIA EM UNIDADE DE TERAPIA INTENSIVA NEONATAL}

\section{Lucio Flavio Garcia Rodrigues*}

Undergraduate in Physical Therapy

Federal University of Pará (UFPA), Belém, PA, Brazil.

Street Augusto Corrêa, 01, University City: José Silveira Neto, Health sector: Guamá, Belém, PA, Brazil. CEP: 66075-110

E-mail: lucioflavio99@gmail.com

\section{Emerson Souza Da Rocha}

Undergraduate in Physical Therapy

Federal University of Pará (UFPA), Belém, PA, Brazil.

Street Augusto Corrêa, 01, University City: José Silveira Neto, Health sector: Guamá, Belém, PA, Brazil. CEP: 66075-110

E-mail: emersonrochaa1@gmail.com

\section{Isabelle Coelho da Silva}

Undergraduate in Physical Therapy

University of Amazon (ESAMAZ), Belém, PA, Brazil

Street Municipalidade, 546 - Reduto,Belém, PA, Brazil. CEP: 66053-180.

E-mail: isabellecsilva21@gmail.com

\section{Luciana de Fátima da Costa Moraes}

Graduate in Physical Therapy, Low

University of Amazon (ESAMAZ), Belém, PA, Brazil

Street Municipalidade, 546 - Reduto,Belém, PA, Brazil. CEP: 66053-180.

E-mail: lfcmoraes@hotmail.com

\section{Laura Maria Tomazi Neves}

$\mathrm{PhD}$ in Physical Therapy

Federal University of Pará (UFPA), Belém, PA, Brazil.

Street Augusto Corrêa, 01, University City: José Silveira Neto, Health sector: Guamá, Belém,

PA, Brazil. CEP: 66075-110

E-mail: 1mtomazi@gmail.com

\section{Denise da Silva Pinto}

Doctorate in Tropical Diseases

Federal University of Pará (UFPA), Belém, PA, Brazil. 
Street Augusto Corrêa, 01, University City: José Silveira Neto, Health sector: Guamá, Belém, PA, Brazil. CEP: 66075-110

E-mail: denisepinto@ufpa.br

\title{
Natália Silva da Costa
}

Graduate in Physical education University of Amazon (UNAMA), Belém, PA, Brazil. Street Alcindo Cacela, 287 - Umarizal, Belém, PA, Brazil. CEP: 66060-000

E-mail: ns.costa5@gmail.com

\section{João Simão de Melo-Neto}

Phd in health Sciences, Federal University of Pará (UFPA), Belém, PA, Brazil. Street Augusto Corrêa, 01, University City: José Silveira Neto, Health sector: Guamá, Belém, PA, Brazil. CEP: 66075-110

E-mail: jsmeloneto@gmail.com

${ }^{*}$ Corresponding author at

\begin{abstract}
Objective: To analyze whether maternal, obstetric, anthropometric data of the neonate and respiratory variables influence the use of BHMs in neonates admitted to the NICU. In addition, to evaluate the impact of the applicability of this type of technique on the morbidity, mortality and survival of these neonates. Methods: Retrospective, quantitative study with descriptive and inferential analysis. Initially, the sample consisted of 599 medical records. The study involved newborns of both sexes admitted to the Neonatal Intensive Care Unit (NICU) of the tertiary referral hospital at maternal and child health, during 2017. The respiratory variables, maternal, obstetric, data of the neonate, morbidity and mortality were selected. Results: BHMs were associated with neonates whose mothers had a number of pregnancies $\geq 3$ or newborns who had cephalic presentation at the time of delivery. In addition, there are particularities among neonates who receive this intervention, such as higher capillary glycemia, lower head circumference and occurrence of jaundice. The technique was not related to prematurity factors, such as pregnancy time $\leq 24$ weeks, or respiratory factors, such as apnea, flapping of the nose wing, cyanosis and intercostal retraction. However, the use of the BHMs increases neonatal survival and reduces the mortality. Conclusion: The BHMs use is determined by maternal, obstetric and neonatal variables, being determinant to reduce the risk of death and increase the survival in NICU.
\end{abstract}

Keywords: Intensive Care Units, Pregnancy, Infant mortality, Respiratory system, Survival analysis.

\section{RESUMO}

Objetivo: Analisar se dados maternos, obstétricos, antropométricos e variáveis respiratórias influenciam o uso de BHMs em neonatos internados em UTIN. Além disso, avaliar o impacto da aplicabilidade desse tipo de técnica na morbimortalidade e sobrevida desses neonatos. Métodos: Estudo retrospectivo, quantitativo com análise descritiva e inferencial. Inicialmente, a amostra era composta por 599 prontuários. O estudo envolveu recém-nascidos de ambos os sexos internados na Unidade de Terapia Intensiva Neonatal (UTIN) do hospital terciário de 
referência em saúde materno-infantil, durante 2017. Foram selecionadas as variáveis respiratórias, maternas, obstétricas, dados do neonato, morbimortalidade. Resultados: os BHMs foram associados a neonatos cujas mães tiveram um número de gestações $\geq 3$ ou recém-nascidos que apresentaram apresentação cefálica no momento do parto. Além disso, existem particularidades entre os neonatos que recebem essa intervenção, como aumento da glicemia capilar, menor perímetro cefálico e ocorrência de icterícia. A técnica não foi relacionada a fatores de prematuridade, como tempo de gestação $\leq 24$ semanas, ou fatores respiratórios, como apneia, batimento da asa nasal, cianose e retração intercostal. Porém, o uso dos BHMs aumenta a sobrevida neonatal e reduz a mortalidade. Conclusão: $\mathrm{O}$ uso de BHMs é determinado por variáveis maternas, obstétricas e neonatais, sendo determinante para reduzir o risco de óbito e aumentar a sobrevida em UTIN.

Palavras-chave: Unidades de Terapia Intensiva, Gravidez, Mortalidade infantil, Sistema respiratório, Análise de sobrevivência.

\section{INTRODUCTION}

The Neonatal Intensive Care Unit (NICU) is a place with physical and human resources ideal for the care of complex situations. Directed to the care of high-risk newborns, providing an inpatient service and comprehensive care to neonates who present complications and/or anormalities that may generate risk of death. Premature newborns (gestational age less than 30 weeks; less than $1 \mathrm{~kg}$ ) who need or have undergone invasive and/or high complexity procedures are also directed to NICU care. The immediate identification of all these conditions are essential for the maintenance and recovery of neonatal health [1].

In this intensive environment, several professionals work in an interdisciplinary manner, favoring the neonatal prognosis with different techniques. In the vast majority of intensive care units, the physiotherapist is a team member who works in the care and comprehensive management of patients in need of respiratory support. The physical therapist's action ensures actions of prevention, promotion, education, intervention and rehabilitation of the patient. In addition, it acts by applying methods, techniques and resources that ensure functionality and better lung capacity through secretion removal, muscle strengthening, cardiorespiratory reconditioning and ventilatory support of critical or potentially critical patients [2-3].

Among the techniques used by this professional in this intensive environment are the Bronchial Hygiene Maneuvers (BHMs), which have the basis of their application based on the retention of excess secretion in the respiratory tract through kinetic procedures, postural and manual techniques [4]. 
BHMs are widely used in NICU-directed patients, however, there are gaps in knowledge about these techniques. Thus, it is necessary to evaluate how some variables such as maternal, obstetric and neonatal factors such as anthropometric data and perinatal complications can influence the evolution of the newborn's condition so that he or she needs intervention through these techniques or not.

Respiratory problems are the ones that cause the most increases in complication rates and hospitalizations among neonates, due to inefficient maturity of the respiratory system, bigger susceptibility to infection, changes in development and lung growth in the prenatal period. In addition, most neonatal respiratory problems appear in the first hours of life, in a nonspecific presentation with overlap of signs and symptoms in most cases [5-6].

Women and newborns are more vulnerable to complications during and immediately after childbirth. About 2.8 million newborns die each year, one every 11 seconds, mostly from preventable causes and in developing countries [7]. Given the occurrence of infant mortality, the follow-up of mothers is extremely important. Prenatal care cannot predict all possible complications that this mother may develop, however, it helps to reduce risk factors that may favor a worse infant prognosis, referring to other levels of care if necessary [8].

In addition to harming the health and quality of life of mothers, children and family members, the birth of neonates with complications generate high costs to hospitals, being responsible for $65 \%$ of hospital expenses in referral units. In addition to expenses and investments in technologies for early diagnosis and cost of hospitalizations of pregnant women whose neonates have complications [9].

Therefore, the aim of this study is to analyze whether maternal, obstetric, anthropometric data of the neonate and respiratory variables influence the use of BHMs in neonates admitted to the NICU. In addition, to evaluate the impact of the applicability of this type of technique on the mortality and survival of these neonates.

\section{MATERIALS AND METHODS}

\section{ETHICAL ASPECTS}

The research was conducted after approval by the Research Ethics Committee, n. $2,442,015$. The design was performed in accordance with the ethical principles provided in Resolution 466/12 of the National Health Council of Brazil and was conducted as per the 
Declaration of Helsinki. The term of consent was not necessary because it is a retrospective study of data collection from medical records.

\section{STUDY DESIGN}

This study was designed as a retrospective, quantitative study with descriptive and inferential analysis.

\section{PLACE AND PERIOD OF STUDY}

The study collected data from the medical records of patients admitted at the NICU of Santa Casa de Misericórdia de Belém, PA, Brazil, during 2017. The hospital is a tertiary reference center for maternal and child health.

\section{SAMPLING}

Sampling was probability-based. It was a simple random sample.

\section{SAMPLE}

Data from 651 medical records were initially randomly collected in 2017. Each medical record was assessed to determine whether all the necessary items were correctly filled in and written legibly before inclusion for analysis. The study involved neonates of both sexes admitted to the neonatal intensive care unit (NICU). Of these, 599 were selected after considering the inclusion and exclusion criteria. Then, divided between the bronchial hygiene groups present $[$ BHMs $(+)](n=400)$ and absent $[$ BHMs $(-)](n=199)$ because they met the inclusion and exclusion criteria.

The minimum number of 185 medical records [BHMs $(+) n=131$; BHMs $(-) n=54$ ] was needed for the analysis, based on sample size calculations and pilot data from this study. Analyses were performed using the odds ratio (OR: 2.862). The association between the use of cephalic fetal presentation and BHMs was analyzed. For this calculation, the following parameters were established: one-tail, proportion $\mathrm{p} 2$ : 0.74 , relation of allocation N2/N1: 0.41, error $\alpha=0.05$, and $\beta=0.2$.

\section{INCLUSION CRITERIA}

This study included the medical records of neonates admitidos in NICU 


\section{EXCLUSION CRITERIA}

Incomplete medical records were excluded from the study and the absence of information on the execution of BHMs, as a physiotherapy service provided was a determining factor. In the medical records, this information was categorized.

\section{DATA COLLECTION}

For data collection, we used a form elaborated by the authors, including maternal factors, obstetric factors, and anthropometric and postnatal variables of the newborn. After completing the form, all data were tabulated and compared to verify the relationship between the values.

\section{PRIMARY OUTCOMES}

Neonatal outcomes were: sex, Apgar score, height $(\mathrm{cm})$, weight $(\mathrm{g})$, cephalic perimeter $(\mathrm{cm})$, thoracic perimeter $(\mathrm{cm})$, abdominal perimeter $(\mathrm{cm})$ and capillary glycemia. The respiratory signs analyzed were: Signs of respiratory failure (apnea, cyanosis, flapping of the nose wing (FNW), wailing and retraction), resuscitation maneuvers, ventilatory support (continuous positive airway pressure [CPAP], invasive mechanical ventilation [IMV] and surfactant), complications (jaundice, respiratory distress, atelectasis, pneumonia) and mortality.

\section{STATISTICAL ANALYSIS}

After verifying the normality of the data via the Lilliefors test, they were presented as means and standard deviations (parametric) or medians with $95 \%$ confidence intervals $(95 \%$ CI) (non-parametric). To verify intergroup differences, non-paired t Test (parametric data) and Mann-Whitney Test (nonparametric data) were used. Categorical variables were presented as absolute and relative frequencies. The chi-squared $\left(\chi^{2}\right)$ test with Yates's correction was used to analyze the association between categorical variables. To quantify the level of association, Odds ratios (OR) with $95 \%$ CI were used. To survival and length of stay analysis, the Kaplan-Meier curve was applied to verify the difference and the Log-rank, Breslow and Tarone-Ware test were used. 


\section{RESULTS}

Maternal age did not differ between groups (BHMs (+): 24 [22-28] years; BHMs (-): 24 [21-29] years; Mann-Whitney test $\mathrm{p}=0.8529)$. Male neonates were more prevalent in both groups $($ BHMs $(+): \mathrm{n}=226$; BHMs $(-): \mathrm{n}=114)$. Maternal age did not differ between groups (BHMs (+): 24 [22-28] years; BHMs (-): 24 [21-29] years; Mann-Whitney test $\mathrm{p}=0.8529$ ). Male neonates were more prevalent in both groups (BHMs $(+): n=226$; BHMs $(-): n=114)$.

The maternal and obstetric factors analyzed are present in table 1. The time of pregnancy $\leq 24$ weeks was more associated with the non-use of bronchial hygiene maneuvers. In addition, the number of pregnancies $\geq 03$ and cephalic presentation at the time of delivery were more associated with the maneuvers.

Table 2 shows the anthropometric data of neonates and their relationship with the use or not of the BHMs. It was observed that the patients who received bronchial hygiene maneuvers were those who had higher capillary glycemia and lower thoracic perimeter.

Table 3 shows postnatal data, which include respiratory signs, morbidity and mortality. Neonates who presented apnea, FNW, cyanosis and intercostal retraction were more associated with the non-use of BHMs. Patients who presented jaundice and atelectasis, there was an association with the use of the technique. In addition, neonates who did not receive the intervention were more likely to have an outcome in death.

Figure 1 shows the Kaplan-Meier curve of neonates admitted to a neonatal intensive care unit. The analysis revealed that newborns who received BHM had longer survival than those who did not receive the intervention (Figure 1A). Among the neonates who were discharged, there was no difference between the groups (Figure 1B).

\section{DISCUSSION}

Our sample presented a prevalence of male neonates in both groups. In fact, there is a "disadvantage" regarding gender difference, as observed in respiratory morbidity and mortality of male newborns described since 1933 reporting the incidence of chronic lung disease and respiratory distress syndrome represented by higher rates than individuals of female [10-11].

Despite advances in technologies and interventions to support the survival of newborns, neonatal death remains a serious public health problem in developing countries [12]. Thus, this study was carried out to analyze how maternal, obstetric and neonatal variables influence the use of BHMs in NICU. In addition, to analyze whether the use of the maneuvers decreases morbidity, mortality and increases survival. 
BHMs are resources widely used by physiotherapists in intensive care. They aim to prevent complications that may be directly associated with the accumulation of nose secretions, even if the technique presents heterogeneous evidence as to its effectiveness, which directly affects its possible limitations, including the instruments used to measure clinical practice [13-15]. In addition to the characterization of each situation that is indicated a mode of ventilation, the ventilatory adjustments in the newborn should be individualized, taking into account the circumstance [16].

In the present study, there is an influence of variables on the use of the BHMs. Characteristics such as shorter gestational time increase the chances of prematurely born neonates being more likely to suffer major morbidities such as breathing difficulties, which is the largest contributor to infant mortality as a respiratory disease, and may be represented by insufficient surfactant, production that has progressively increased production during pregnancy, peaking around the 35th week [17]. Our study showed that the application of BHMs techniques were not predominant among neonates who had shorter time of pregnancy. Then, our hypothesis is that the manipulation by manual therapeutic maneuvers are avoided in these premature neonates due to physical frailty.

Our study showed a prevalence of BHMs in neonates of multiparous mothers of 3 or more pregnancies. This relationship can be caused by consequences of multiparity, as described in a study [18]. That found a high prevalence of spontaneous preterm delivery (GA $<37,<32$ and $<28$ weeks of gestation) in multiparous women in the 4 th or 5th pregnancy, as well as higher numbers of pregnancies to the detriment of those who had 1,2 or 3 pregnancies, suggesting that the increase in the number of parity is proportional to the risk of premature delivery and consequently to the occurrence of respiratory distress. A condition that can be requires interventions, such as BHMs.

We found in our study that the use of the technique was more associated with neonates who had cephalic presentation $(\mathrm{p}=0.0001)$ during delivery. However, Meye et al [19]. when comparing pelvic and cephalic deliveries, observed a five-fold greater association of mortality in neonates with cephalic presentation. Thus, we believe that neonates from cephalic delivery who require ICU usually have a worse clinical status.

Respiratory distress is a syndrome that mainly affects premature babies, affecting about $1 \%$ of premature infants. This condition is a consequence of several perinatal and postnatal events such as meconium aspiration, sepsis, pneumothorax, delayed transition and 
infections, and has as a risk factor premature delivery and cesarean delivery [20]. In the groups of BHMs present and missing BHMs, all respiratory signs evaluated (apnea, FNW, cyanosis and intercostal retractor) were more associated with the preference for not using BHMs techniques [21].

Apnea is characterized as an interruption of breathing for 20 seconds or more, or short pause followed by bradycardia, cyanosis, or pallor. The proportion of apnea in a newborn increases as the gestation time decreases [22]. The risk of its occurrence in neonates is due to natural anatomo-physiological characteristics of this period such as smaller diameter airways, immature intercostal and diaphragmatic muscle function, and lower pulmonary compliance. Especially in neonates under intensive care it is common to find individuals who have immaturity of respiratory centers and airway reflexes [23].

Due to the causes of apnea mentioned above in our study, we observed that the bronchial hygiene maneuvers is not the most appropriate physical therapy approach to treat this condition, since it aims to mobilize secretions from the pulmonary periphery to the central pathways so that they are expelled or aspirated and apnea has its resolution through other direct interventions such as treatment with methylxane-based drugs, nasal continuous positive airway pressure (NCPAP) and blood transfusion [24].

The FNW is a sign of common respiratory distress in patients under intensive care clinically associated with the occurrence of taquipnea [25]. Another common clinical sign in hospitalized newborns is the intercostal retraction, which indicates the use of accessory muscles for breathing, can be caused by inflammatory conditions in the lower airways such as bronchiolitis, which is also manifested through the presence of mucus. In NICU, it can be treated with the aid of mechanical ventilation, which can increase the production and accumulation of these secretions in the airways, and then necessary intervention to eliminate secretion through bronchial hygiene maneuvers [26].

Among the neonatal complications studied, we found an association between the occurrence of jaundice and the performance of the BHMs technique, demonstrating that the occurrence of this complication is not a predictive factor for performing these maneuvers. Neonatal jaundice is a clinical condition that presents recurrent among neonates, however, if not adequately treated it can cause severe morbidities and even lead the newborn to death [27]. Its mechanism is caused by high bilirubin levels and is present in about $80 \%$ of premature newborns and $60 \%$ of full-term newborns. Of multifactorial causes, it is mainly 
due to immaturity of the liver. Treatment of this condition is by phototherapy and is generally not harmful, however, if the condition is prolonged or if bilirubin levels are too high, there are chances to develop a condition called kernicterus, characterized by permanent neurological damage. Although it does not have direct repercussions on the respiratory system, its high prevalence among premature newborns may justify our findings, since these newborns usually have their immature vital organs [28].

Capillary glycemia increase is another parameter associated with the use of BHMs. This condition is common in metabolic alteration especially in premature neonates [29]. The increase of glycemia has been associated with several morbidities during the neonatal period. It can cause changes in blood parameters and make the newborn more susceptible to infections, besides being associated with a higher mortality rate in clinical studies. However, we highlight that blood glucose levels are within the limits assigned as normal, since the capillary hyperglycemia present an interstitial glucose concentration $>144 \mathrm{mg} / \mathrm{dl}(>8 \mathrm{mmol}$ / L) [30].

Neonates from the both of groups had a thoracic perimeter below the normal range (30 to $35 \mathrm{~cm}$ ) [31]. However, the neonates with a lower thoracic perimeter were less submitted to BHMs in the NICU. The physical fragility of the neonatal in reducing the application of the maneuver should be taken into account. In addition, the prediction of the outcome mortality and survival can be performed from the analysis of certain anthropometric data such as thoracic perimeter [32]. One study noted that there is a high correlation between this measure and low birth weight, indicating that premature neonate patients in the intensive care and coupled for weeks with ventilatory techniques due to secretions present risk factors for survival [33]. This fact may make this newborn more susceptible to complications in the intensive environment. These complications are commonly described in the literature associated with pathologies such as pneumonia or signs of respiratory failure [34]. The lack of BHMs makes the neonate more secretive and therefore prone to partial or complete obstruction of the alveolos. Thus, the bronchial hygiene maneuvers, as well as surfactant stimulation, is necessary for the obstruction to be reparated and the conditioning of the alveolos can be regularized, contributing to the reduction of mortality from obstruction [35-36].

Neonatal respiratory diseases manifest in preterm infants in the first hours of life due to pulmonary immaturity, thus it is necessary to help ventilatory support to promote 
functional respiratory independence and accelerate the recovery of the newborn [37]. The physiotherapeutic intervention by means of bronchial hygiene maneuvers is commonly used in the daily routine of The NICU, indicating greater ease for mucus movement, and may be associated with the reduction of the mortality of neonates [38]. Thus, we added that in our study the application of the maneuver was associated with higher survival and lower mortality. However, more research is needed to justify such an impact, since its cause is multifactorial.

The limitations for this study included the data collection process, involving localization, variations in the insertion of maneuvering conducts and incomplete data of some variables. These difficulties are presented by epidemiological studies, especially those conducted in Brazil [39].

\section{CONCLUSION}

BHMs were associated with neonates whose mothers had a number of pregnancies $\geq 3$ or newborns who had cephalic presentation at the time of delivery. In addition, there are particularities among neonates who receive this intervention, such as higher capillary glycemia, lower head circumference and occurrence of jaundice. The technique was not related to prematurity factors, such as pregnancy time $\leq 24$ weeks, or respiratory factors, such as apnea, FNW, cyanosis and intercostal retraction. However, the use of the BHMs increases neonatal survival and reduces the mortality. In conclusion, the BHMs use is determined by maternal, obstetric and neonatal variables, being determinant to reduce the risk of death and increase the survival in NICU.

\section{ACKNOWLEDGEMENT}

We thank the Tertiary Reference Hospital in maternal and child health Fundação Santa Casa de Misericórdia do Pará - Brazil and the Laboratory of Clinical and Experimental Research of the Urogenital System (UPCEURG - UFPA).

\section{DECLARATIONS OF INTEREST}

The authors declare no conflict of interest.

\section{AUTHORS 'CONTRIBUTION}

All authors contributed equally to the design and writing of the manuscript. All authors they critically reviewed the manuscript and approved the final version. 


\section{FUNDING SOURCES}

This research did not receive any specific grant from funding agencies in the public, commercial, or not-for-profit sectors.

\section{REFERENCES}

1. Faria, T.F. y Kamada I. Vista de Lesiones de la piel en neonatos en cuidados intensivos neonatales. Enferm Glob. 2018;17(49):211-36.6.

https://doi.org/10.6018/eglobal.17.1.273671.

2. RESOLUÇÃO N. 402/2011 - Disciplina a Especialidade Profissional Fisioterapia em Terapia Intensiva e dá outras providências. COFFITO.

3. Juultje S, Raoul E, Daniela D, Rik G, Peter S, Frans N, Marike S. Physiotherapy in the intensive care unit: an evidence-based, expert driven, practical statement and rehabilitation recommendations. Clin Rehabil. 2015;29(11):1051-1063.

https://doi.org/10.1177/0269215514567156

4. Matilde I, Eid R, Nunes A, Ambrozin ARP, Moura R, Carnieli-Cazati D, Timenetsky K. Bronchial hygiene techniques in patients on mechanical ventilation: what are used and why? einstein (São Paulo). 2018;16(1):eAO3856. https://doi.org/10.1590/S1679-45082018AO3856

5. Angelica D, Roberta W, Crislaine P. Profile of neonates hospitalized at a neonatal intensive care unit: a cross-sectional study. Arq. Ciênc. Saúde. 2016;23(2) 1 00-105.

https://doi.org/10.17696/2318-3691.23.2.2016.308

6. Ministério da Saúde. Atenção à saúde do recém-nascido: guia para os profissionais de saúde [monografia na Internet].2. ed.Brasília (DF): Ministério da Saúde.

http://bvsms.saude.gov.br/bvs/publicacoes/atencao_saude_recem_nascido_profissionais_v1.p df. 2012. Accessed 14 July 20.

7. Pan American Health Organization, World Health Organization. Levels and trends in the 2019 infant mortality report.

https://www.who.int/maternal_child_adolescent/documents/levels_trends_child_mortality_20 19/en/. Accessed 18 July 20.

8. Rayburn WF. At-risk pregnancies. Obstet Gynecol Clin North Am. 2015 Jun;42(2):xiii-xiv. https://doi.org/10.1016/j.ogc.2015.02.002.

9. Chapman CS, Kern A, Laguecir A. Quentin W. Management accounting and efficiency in health services: the foundational role of cost analysis. European Observatory on Health Systems and Policies. 2016;

10. Wyllie, J. Sex Differences in Infant Mortality. Canadian Public Health Journal. 1933:177-185. 
11. Ben-Shmuel, A., Sheiner, E., Wainstock, T., Landau, D., Vaknin, F., \& Walfisch, A. The association between gender and pediatric respiratory morbidity. Pediatric Pulmonology. 2018. https://doi.org/10.1002/ppul.24083

12. Sankar MJ, Natarajan CK, Das RR, Agarwal R, Chandrasekaran A, Paul VK. When do newborns die? A systematic review of timing of overall and cause-specific neonatal deaths in developing countries. J Perinatol. 2016;36:S1-S11. https://doi.org/10.1038/jp.2016.27

13. Oliveira TC, Moda GSM, Ribeiro AKPL, Nunes SED, Araújo RA, Gaia VSC. Bronchic hygiene techniques in newborns and infants in the intensive care unit: systematic review of clinical trials. J Phys Res. 2018;8(3):420-429. https://doi.org/

10.17267/2238-2704rpf.v8i3.1958

14. Dubb R, Nydahl P, Hermes C, Schwabbauer N, Toonstra A, Parker AM, Kaltwasser A, Needham DM. Barriers and Strategies for Early Mobilization of Patients in Intensive Care Units. Ann Am Thorac Soc. 2016;13(5):724-30. https://doi.org/

10.1513/AnnalsATS.201509-586CME

15. Avva U, Lata JM, Kiel J. Airway Management. [Updated 2020 Mar 18]. In: StatPearls [Internet]. Treasure Island (FL): StatPearls; 2020.

16. Unoki T, Kawasaki Y, Mizutani T, Fujino Y, Yanagisawa Y, Ishimatsu S, Tamura F, Toyooka H. Effects of expiratory rib-cage compression on oxygenation, ventilation, and airway-secretion removal in patients receiving mechanical ventilation. Respir Care. 2005;50(11):1430-7.

17. Townsel CD, Emmer SF, Campbell WA, Hussain N. Gender Differences in Respiratory Morbidity and Mortality of Preeterm Neonates. Front Pediatr. 2017; 5: 6.

https://doi.org/10.3389/fped.2017.00006

18. Koullali B, van Zijl MD, Kazemier BM, et al. The association between parity and spontaneous preterm birth: a population based study. BMC Pregnancy Childbirth. 2020. https://doi.org/10.1186/s12884-020-02940-w

19. Meye JF, Mayi S, Zue AS, Engongah-Beka T, Kendjo E, Ole BS. Neonatal prognosis for breech infants delivered vaginally at the Josephine Bongo Maternity Hospital in Libreville, Gabon. Santé. 2003;13:81-4.

20. Hermansen, Christian L, and Anand Mahajan. Newborn Respiratory Distress. American family physician. 2015;994-1002

21. Kao S, Morris H, Lally P, Stewart D, Huseby V, Kennedy A. Hyperglycemia and morbidity and mortality in extremely low birth weight infants. $J$ Perinatol. 2006;26(12):730-6. https://doi.org/10.1038/sj.jp.7211593

22. Eichenwald EC; Committee on Fetus and Newborn, American Academy of Pediatrics. Apnea of Prematurity. Pediatrics. 2016 Jan;137(1). Epub 2015 Dec 1.

https://doi.org/10.1542/peds.2015-3757 
23. Tropiano L, Azevedo A, Fernandes M, Salerno G, Vianna D, Santos . Relação entre incidência de apneia em recém nascidos e consumo materno de cafeína na gestação. Cadernos de Pós-Graduação em Distúrbios do Desenvolvimento. 2016;16(1), 8-16. https://doi.org/10.22310/1809-4139/cpdd.v16n1p8-16

24. ichenwald EC; Committee on Fetus and Newborn, American Academy of Pediatrics. Apnea of Pre.maturity. Apnea of Prematurity. Pediatrics. 2016 Jan;137(1).

https://doi.org/10.1542/peds.2015-3757

25. Edwards O, Kotecha J, Kotecha S. Respiratory distress of the term newborn infant. Paediatric respiratory reviews. 2013;14(1), 29-37. https://doi.org/10.1016/j.prrv.2012.02.002

26. Christian L, Anand M. Newborn Respiratory Distress. Am Fam Physician. 2015;1:92(11):994-1002.

27. Guidelines for detection, management and prevention of hyperbilirubinemia in term and late preterm newborn infants (35 or more weeks' gestation). Paediatr Child Health. 2007;12(5):401-407. https://doi.org/10.1093/pch/12.5.401

28. Brits H, Adendorff J, Huisamen D, Beukes D, Botha K, Herbst H, Joubert G. The prevalence of neonatal jaundice and risk factors in healthy term neonates at national district hospital in Bloemfontein. Afr J Prim Health Care Fam Med. 2018;12;10(1):e1-e6. https://doi.org/10.4102/phcfm.v10i1.1582

29. Rozance, P. J., \& Hay, W. W. Neonatal Hyperglycemia. NeoReviews. 2010;11(11):e632-e639. https://doi.org/10.1542/neo.11-11-e632

30. Shah R, McKinlay CJD, Harding JE. Neonatal hypoglycemia: continuous glucose monitoring. Curr Opin Pediatr. 2018;30(2):204-208.

https://doi.org/10.1097/MOP.0000000000000592

31. Centenaro O, Getelina CO, dos Santos Cargnin MC, Franciscatto LHG, Rheinheimer V, Pereira V. Primitive Reflexes of Neonates Born in a Maternity in the Rio Grande do Sul State. Revista de Pesquisa, Cuidado é Fundamental Online. 2019;11(3):588-593.

https://doi.org/10.9789/2175-5361.2019.v11i2.588-593

32. Hadush MY, Berhe AH, Medhanyie AA. Foot length, chest and head circumference measurements in detection of Low birth weight neonates in Mekelle, Ethiopia: a hospital based cross sectional study. BMC Pediatr. 2017. 21;17(1):111.

https://doi.org/10.1186/s12887-017-0866-0

32. Choi YB, Lee J, Park J, Jun YH. Impact of Prolonged Mechanical Ventilation in Very Low Birth Weight Infants: Results From a National Cohort Study. J Pediatr. 2018. 34-39.e3. https://doi.org/10.1016/j.jpeds.2017.10.042.

33. Marangu D, Zar HJ. Childhood pneumonia in low-and-middle-income countries: An update. Paediatr Respir Rev. 2019. 32:3-9. https://doi.org/10.1016/j.prrv.2019.06.001. 
34. Matilde IN, Eid RA, Nunes AF, Ambrozin AR, Moura RH, Carnieli-Cazati D, et al.

Manobras de higiene brônquica em pacientes em ventilação mecânica: quais e por que são usadas? einstein (São Paulo). 2018;16(1):eAO3856

35. McPherson C, Wambach JA. Prevention and Treatment of Respiratory Distress Syndrome in Preterm Neonates. Neonatal Netw. 2018;1:37(3):169-177.

https://doi.org/10.1891/0730-0832.37.3.169

36. Reuter S, Moser C, Baack M. Respiratory distress in the newborn. Pediatr Rev. 2014;35(10):417-429. https://doi.org/10.1542/pir.35-10-417

37. Naue W, Herve B, Vieira F, Deponti G, Martins L, Dias A, Vieira S. Comparison of bronchial hygiene techniques in mechanically ventilated patients: a randomized clinical trial. Comparação entre técnicas de higiene brônquica em pacientes mecanicamente ventilados: ensaio clínico randomizado. Rev Bras Ter Intensiva. 2019;31(1):39-46.

https://doi.org/10.5935/0103-507X.20190005.

38. Timoteo F, Korkes F, Baccaglini W, Glina S. Bladder cancer trends and mortality in the brazilian public health system. International Brazilian Journal of Urology. 2020;46(2): 224-233. https://doi.org/10.1590/s1677-5538.ibju.2019.0198

39. Melo GS, Andrade EM, Mendonça TS, Santos IBF, Soares CO, Gomes FC, Melo Neto JS. Sobrevida e perfis social, clínico e hemodinâmico de pacientes admitidos em Unidade de Terapia Intensiva que evoluíram a óbito. Revista Eletrônica Acervo Saúde.

2020;12(11),e4012. https://doi.org/10.25248/reas.e4012.2020 
Figures

A

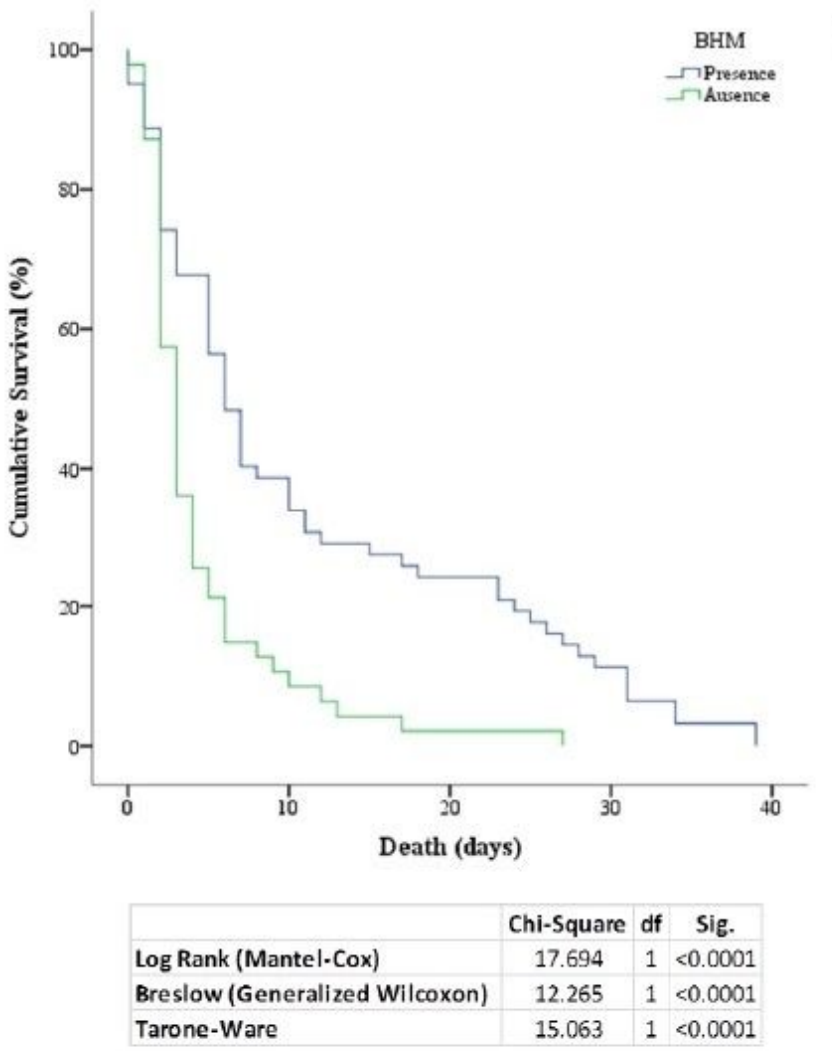

B

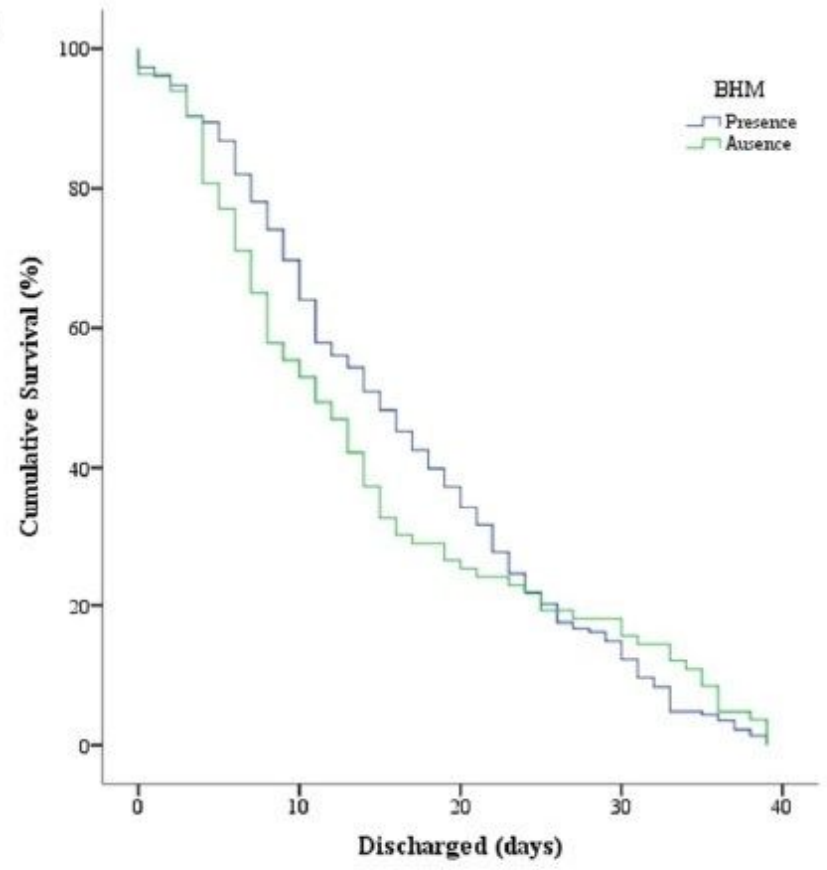

\begin{tabular}{|l|c|c|c|}
\hline & Chi-Square & df & Sig. \\
\hline Log Rank (Mantel-Cox) & 0.131 & 1 & 0.717 \\
\hline Breslow (Generalized Wilcoxon) & 3.452 & 1 & 0.063 \\
\hline Tarone-Ware & 1.735 & 1 & 0.188 \\
\hline
\end{tabular}

Subtitle: BHM: Bronchial Hygiene Maneuver. Source: Rodrigues LFG, et al., 2020.

\section{Figure 1}

Kaplan-Meier curve of neonates admitted to an intensive care unit. A. Mortality. B. Discharged.

\section{Supplementary Files}

This is a list of supplementary files associated with this preprint. Click to download.

- TablesBMCpediatrics1.pdf 